\title{
Morphological aspects of cell reabsorption in laying queens and workers of Apis mellifera (Hymenoptera, Apidae)
}

\author{
Karina Patrício ${ }^{1,2}$ \& Carminda da Cruz-Landim ${ }^{1}$
}

\begin{abstract}
1. Departamento de Biologia, Instituto de Biociências, Universidade Estadual Paulista (UNESP), Rio Claro, SP, Brazil.
2. Departamento de Zootecnia, Laboratório de Biotecnologia, Universidade de São Paulo (ESALQ), Av. Pádua Dias, 11, São Dimas, 13418-900 Piracicaba, São Paulo, Brazil. (patricioka@gmail.com)
\end{abstract}

\begin{abstract}
The occurrence of cell reabsorption in the ovaries of queens in several rates of laying eggs, artificially impeded of laying, and in nurse workers, of Apis mellifera (Linnaeus, 1758), was studied with light (LM) and transmission electron microscopy (TEM). Two types of structures were described and named by analogy with vertebrates ovarian structures, as corpus luteus, when resulting from the reabsorption of the follicular cells after ovulation, and corpus atresicus when resulting from total follicular reabsorption at any oocyte developmental stage. These structures have the same morphological characteristics and physiological signification in both castes. The corpus luteus occurrence indicates ovulation and its number is correspondent to the queen's rates of oviposition. The presence of this structure in nurse workers ovarioles shows that this caste may lay eggs. The incidence of corpus atresicus in queens decay with the increasing of the oviposition indicating that the inhibition of the normal sequence of oocyte maturation in the ovaries is deleterious. Both, corpus luteus and corpus atresicus incidence may be influenced by environmental factors.
\end{abstract}

KEYWORDS. corpus luteus, corpus atresicus, oviposition, histology, ultrastructure.

\begin{abstract}
RESUMO. Aspectos morfológicos da reabsorção celular em rainhas em postura e operárias de Apis mellifera (Hymenoptera, Apidae). A ocorrência de reabsorção celular nos ovários de Apis mellifera (Linnaeus, 1758) foi estudada em operárias, em rainhas artificialmente impedidas de se acasalarem e em rainhas em postura utilizando microscopia de luz (LM) e eletrônica de transmissão (MET). São descritos dois tipos de estruturas morfológicas, indicativas da ocorrência de reabsorção. Estas estruturas foram denominadas por analogia com estruturas correspondentes presentes nos ovários dos vertebrados. As resultantes de reabsorção das células foliculares depois da ovulação foram denominadas corpos lúteos e as resultantes da reabsorção de todo o folículo, em qualquer fase do desenvolvimento do ovócito, de corpos atrésicos. As estruturas representativas da reabsorção têm as mesmas características morfológicas e significado fisiológico em ambas as castas. A presença de corpo lúteo indica prévia ovulação e seu número corresponde à taxa de postura da rainha e sua presença nas operárias nutridoras mostra que esta casta pode por ovos nesta fase. A incidência de corpos atrésicos em rainhas diminue com o aumento da taxa de postura indicando que a inibição da sequência normal de maturação de ovócitos no ovário é deletéria. Tanto a incidência do corpo lúteo, como do corpo atrésico pode ser influenciada por fatores ambientais.
\end{abstract}

PALAVRAS-CHAVE. Corpo lúteo, corpo atrésico, oviposição, histologia, ulta-estrutura.

In the eusocial insects the female reproductive function is prerogative of the queen, being the worker caste sterile or semi-sterile (ONIONS, 1912; ANDERSON, 1963). In Apis mellifera (Linnaeus, 1758) the workers may develop their ovaries in the queen absence or even in its presence, under certain conditions (PATRícIO \& CRUZLANDIM, 2003, 2004). Nevertheless, the oviposition by the workers in queenright colonies is more frequent then thought before (SAKAGAMI, 1954; KROPÁCOVA \& Haslbachová, 1969), it is done only by few workers, mostly the ones nursering the brood. As vitellogenesis may, however, occurs in the ovaries of several workers (Patrício \& Cruz-Landim, 2004), the maturated oocytes that are not ovulated are reabsorbed. The same fate have the unovulated eggs of the queens (PATRícIo \& CRUZLANDIM, 2003).

The local for queen ovoposition is provided by the workers, in such a way that the general colony homeostasis influenciates the rates of eggs laid by the queen and also the possibility of worker laying (SAKAGAMI et al., 1963).

Several types of cells reabsorption may naturally occur in queens' ovaries and as well induced experimentally by conditions such as nutrients depriving or deficiency of some feeding components necessary to the maturation of the oocyte, virginity of the female or the absence of male individuals to the coupling and the laying in an inappropriate place (LusIS 1963; BELL \& BOHN, 1975). Also any imperfection in the oogenesis development may compromise the oocyte itself and the integrity of the associated nurse and follicular cells inducing cell reabsorption in any phase of follicle development. BERGER \& ABDALLA (2005) speculates that dead of the nurse cells are the main cause of the oocyte reabsorption in A. mellifera virgin queens, but probably defects in the somatic cells may, as well impare the oocyte growth and maturation. The ovarian degenerative structures resulting from this type of cell reabsorption are sometimes named corpus atresicus, by analogy with similar occurrences in vertebrate ovaries.

This work studies these types cells rebsorption accurring in the ovary of queen and nurse workers of $A$. mellifera.

\section{MATERIAL AND METHODS}

Laying queens with high and low oviposition rates, queens prevented of laying by caging were obtained in the Department of Biology from the UNESP Campus in Rio Claro, Brazil. Their ovaries where dissected and 
prepared for examination with light microscopy (LM) and transmission electron microscopy (TEM).

For LM the ovaries were fixed in $4 \%$ paraformaldehyde in $0.1 \mathrm{M}, \mathrm{pH} 7.4$ phosphate buffer and embedded in Leica historesin after dehydration. The sections $6 \mathrm{~mm}$ thick, were stained with hematoxylin and eosin and $1 \%$ toluidine blue, $\mathrm{pH} 4.0$.

For TEM studies the ovaries were fixed in $2 \%$ glutaraldehyde containing $4 \%$ paraformaldehyde in 0.1 $\mathrm{M}$ sodium cacodylate buffer, $\mathrm{pH} 7.4$ during 2 hours at 4 ${ }^{\circ} \mathrm{C}$. After rinsing in the buffer, a post-fixation was carried out in $1 \%$ osmium tetroxide in the same buffer during 2 hours. The pieces were dehydrated in an increasing acetone series $(70-100 \%)$ and embedded in EponAraldite. During dehydration the pieces were left in $1 \%$ uranyl acetate in $10 \%$ acetone overnight. The thin sections were stained with lead citrate, analyzed and photographed under a TEM.

Quantification of reabsorption structures were done in queens beginning oviposition, with high rates of oviposition, in old queens with oviposition decay and in those prevented of laying. Histological slides of four ovaries of each type of queen were used for counting of the reabsorption structures. The counting was accomplished with use of an IMPACT system, attached to a light microscopy.

\section{RESULTS AND DISCUSSION}

In the meroistic polytrophic ovary of A. mellifera the vitellarium contains follicles divided in two chambers, one containing the oocyte located below the other containing the nurse cells, both enveloped by follicular cells (Fig. 1).

The oocytes more advanced in vitellogenesis are located near the proximal end of the ovarioles. The oocytes in the most proximal end of the ovariole, which have finished the growth, vitellogenesis and coriogenesis and, therefore, are ready to be ovulated and still involved by a sheet of flat follicular cells. In these basal oocytes the nurse cells were already dead by the dumping of their cytoplasm content into the oocyte (Fig 2). This occurrence may be considered a very special type of programmed cell death, in which the material of one cell is passed to other until the end (NEzIs et al., 2000).

The meaning of this type of occurrence is the substitution of the oocyte nuclei function by substances produced by the nuclei of cells that have exactly the same genetic constitution since oocyte and nurse cells are clone (KING et al., 1982; KING \& BüNING, 1985; PATRÍcio \& CRUZ-LANDIM, 2006). This type of cellular reabsorption is, therefore, natural and programmed to occur in all polytrophic ovaries of insects.

Another type of natural reabsorption structure is the one formed after the ovulation. After the oocyte leaves the ovariole, the follicular cells collapse into the peritoneal membrane and constitute a clump that temporarily obstruct the ovariole pedicel, preventing a new ovulation by the same ovariole. This clump of cells is named corpus luteus in analogy with the structure formed in the vertebrate ovaries after ovulation. However it does not have the same cellular constitution and function.
The corpus luteus of the insects appear in the LM preparation as a mass of cells without limit definitions (Fig. 3), which in the final phase of reabsorption accumulates lipids, acquiring a natural yellowy color that in part justify the name.

At TEM examination the corpus luteus appear as a mass of cells surrounded by a very convoluted tunica propria (Fig. 4). These cells present the cytoplasm filled with numerous lipid droplets and in the late stage of
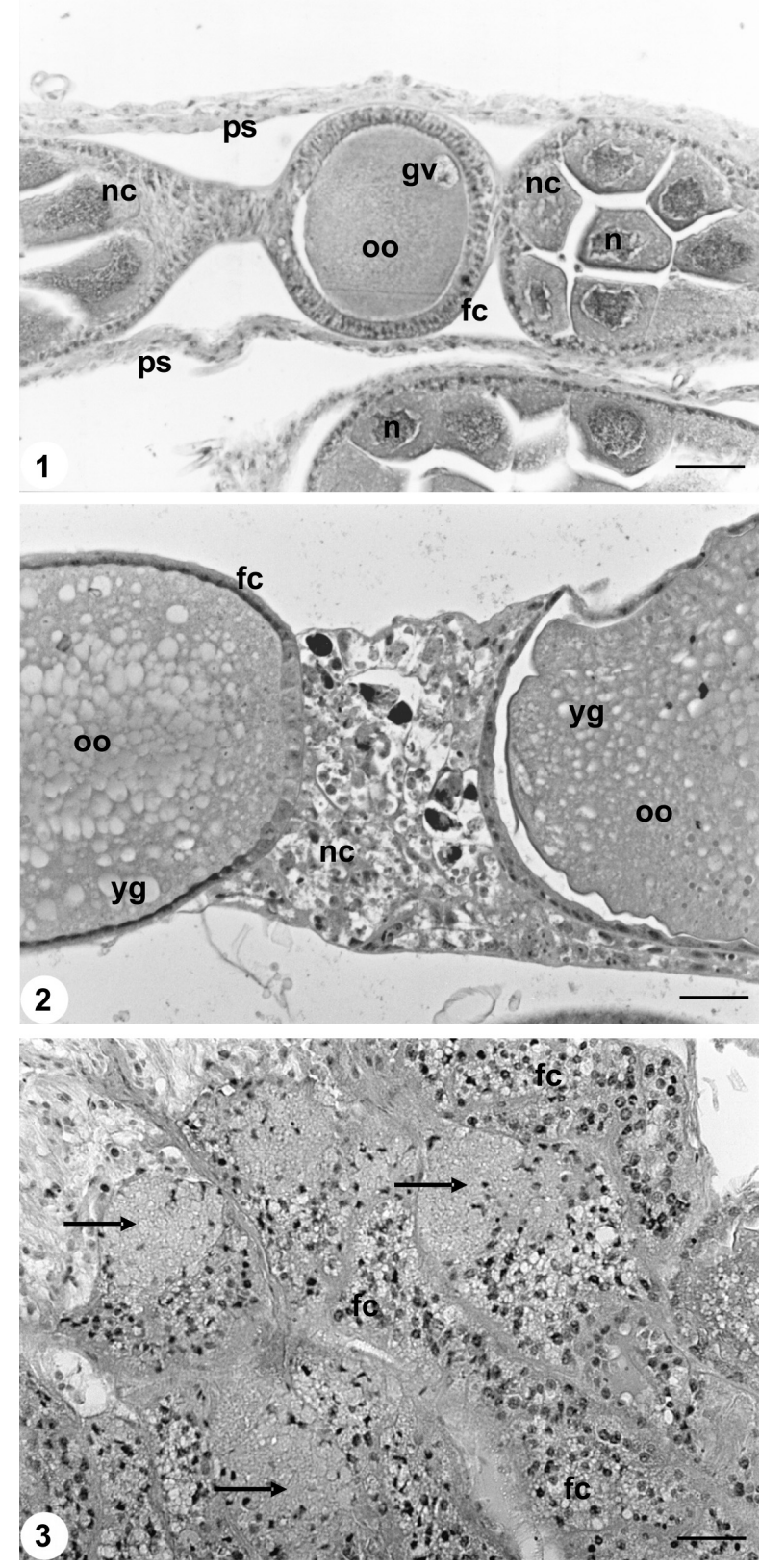

Figs. 1-3. Ovarioles of laying queen of Apis mellifera (Linnaeus, 1758) showing the vitellarium (light microscopy): 1, oocyte and nurse cells differentiation, both enveloped by follicular cells; 2, in the basal region of the oocytes the nurse cells were already dead by the dumping of their cytoplasm content into the oocyte; 3 , oocyte reabsorption place, presenting follicular cells with vacuoles in the final phase of reabsorption which accumulates lipids (arrows) (fc, follicular cells; gv, germinal vesicle; n, nuclei; nc, nurse cells; oo, oocyte; ps, peritoneal sheath; yg, yolk granules). Scale bars: fig. 1, $40 \mu \mathrm{m}$; fig. 2, $30 \mu \mathrm{m}$; fig. 3, $50 \mu \mathrm{m}$. 
degeneration, finally disintegrate (Fig. 5). Probably their rests are eliminated throughout the ovariole pedicel into the lateral ovidut, leaving the way free for a new ovulation.

The corpus luteus from the queen and worker ovaries presents the same morphology (Fig. 6). This type of cellular degeneration, used to be known by the histologists as lipidic degeneration, and is also a type of programmed cell death, since it is programmed to occur ever time that an ovulation takes place.

The presence of corpus luteus as a sign of ovulation permits the confirmation of egg laying. As
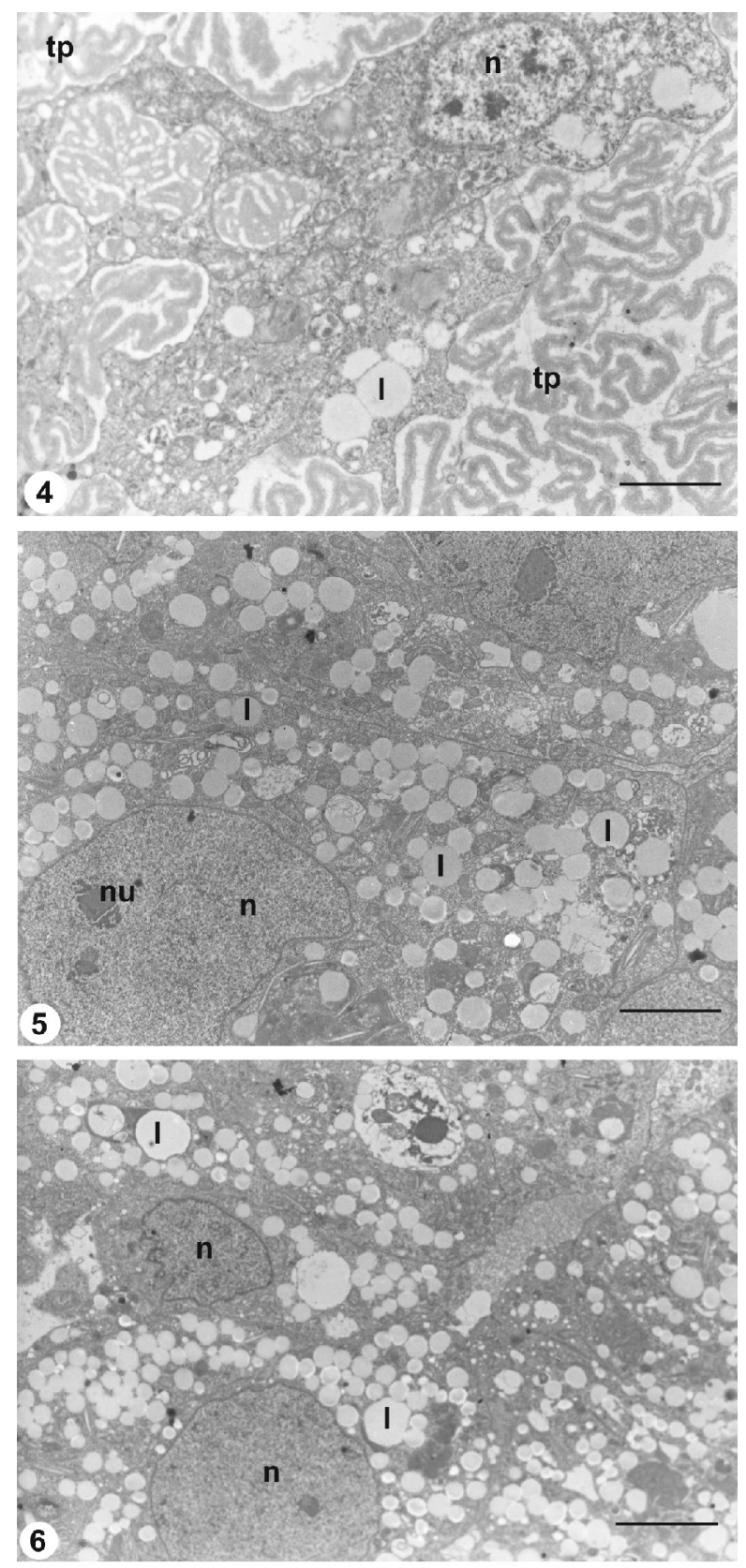

Figs. 4-6. Transmission electron microscopy image of a corpus luteus from queen and worker ovaries of Apis mellifera (Linnaeus, 1758): 4, mass of cells surrounded by a very convoluted tunica propria in laying queen; 5, cytoplasm with numerous lipid droplets in laying queen; 6, corpus luteus of worker showing the cytoplasm with numerous lipid droplets (1, lipid droplets; n, nuclei; nu, nucleolus; tp, tunica propria). Scale bars: $1 \mu \mathrm{m}$. several ovaries dissected from nurse workers presented corpus luteus in the ovarioles, it reveals that oviposition by the workers is not as rare as thought (PATRícIO \& CRUZLANDIM, 2003, 2004).

Another natural degenerative feature in the ovary vitellarium is the follicle atresy. This type of degeneration may occur in the follicle at any phase of development. This structure formed by this type of degeneration, affect all types of cells that constitute the follicle, although seems to be started by the oocyte.

Corpus atresius and corpus luteus normally present in the queen ovary, however, do not appear at the same rates in young and old queens (Fig. 7). In the beginning of the queen oviposition the number of corpus luteus is low, increases in the queens with high rates of oviposition and in old queens, while the number of corpus atresicus decreases with the queen age. In the queens that were impeded of laying eggs there are several atresic regions all over the ovarian ovarioles. If a fecundated and ovipositioning queen is caged and can not lay eggs, corpus lutteus is not seen in its ovarioles but the rates of corpus atresius are elevated. The types of cell death occurring, although may not be included in any described type of cell death, they are considered as physiologically programmed. Even the cell death experimentally induced follows the pattern of the natural cell death, therefore, it is possible that the same mechanisms are actuating in the cells during their reabsorption.

Therefore, the quantification results show that the atresy in the queen ovary decreased in function of the queen physiological and environmental conditions. In the present case the atresy decreased as the fecundated queen enters in a regular rhythm of oviposition meaning that the delaying of the progress of the vitellogenesis by the absence of posture conditions is deleterious to the oogenesis. The atresy that occurs in these conditions does not affect the fertility of the queen. The intensification of the atresy, however, may have other causes environmental or genetic that may prejudice its fertility.

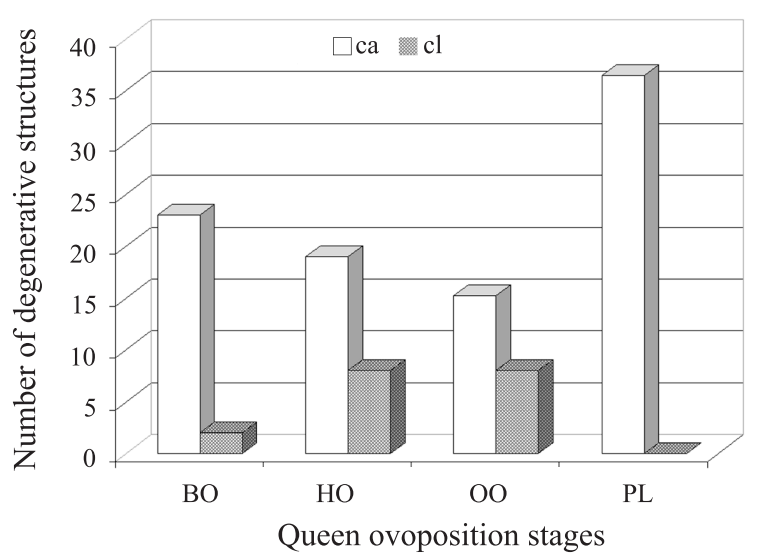

Fig. 7. Ovary reabsorption structures in queens beginning oviposition (BO), presenting high rates of oviposition $(\mathrm{HO})$, old queens with oviposition decay (OO), and caged queens of Apis mellifera (Linnaeus, 1758), prevented of laying eggs (PL) (ca, corpus atresicus; cl, corpus luteus). 
Acknowledgments. The authors acknowledge the financial supported of Fundação de Amparo à Pesquisa do Estado de São Paulo (Fapesp) (98/00613-0) and Conselho Nacional de Desenvolvimento Científico e Tecnológico (CNPq) 351016/94-5.

\section{REFERENCES}

Anderson, R. H. 1963. The laying worker in the Cape Honeybee, Apis mellifera capensis. Journal of Apicultural Research 2(2):85-92.

BeLl, W. J. \& Bohn, M. K. 1975. Oosorption in insects. Biological Reviews 50:373-96.

Berger, B. \& Abdalla, F. C. 2005. Programmed cell death during ovarian differentiation in queens of Apis mellifera Linne, 1758 (Hymenoptera, Apini). Brazilian Journal of Morphological Science 22:1-4.

King, R. C.; Cassidy, J. D. \& Rousset, A. 1982. A. The formation of clones of interconnect cells during gametogenesis in insects. In: KING, R. C. \& AKaI, H. Insect ultrastructure. New York, Plenum. v.1. p.3-33.

King, R. C. \& BünIng, J. 1985. The origin and functioning of insect oocytes and nurse cells. In: Kerkut, G. A. \& Gilbert, L. I. Comprehensive insect physiology biochemistry and pharmacology. Great Britain, Pergamon. v.1. p.38-77.

Kropácová, S. \& Haslbachová, H. 1969. The development of ovaries in worker honeybees in a queeright colony. Journal of Apicultural Research 8(2):57-64.
LüsIs, O. 1963. Histology and histochemistry of development and resorption in the terminal oocytes of the desert locust Schistocerca gregaria. Quarterly Journal of Microscopical Science 104:57-68.

Nezis, I. P.; Stravopodis, D. J.; Papassideri, I.; Robert-Nicoud, M. \& MaRgaRITIS, L. H. 2000. Actin cytoskeleton reorganization of the apoptotic nurse cells during late developmental stages of oogenesis in Dacus oleae. Cell Motility and Cytoskeleton 48:224-233.

Onions, G. W. 1912. South African "fertile" worker bees. Agricultural Journal of the Union of South Africa 3:720-728.

Patrício, K. \& Cruz-Landim, C. 2003. Apis mellifera (Hymenoptera, Apini) ovary development in queens and in workers from queenright and queenless colonies. Sociobiology 42(3):771-780.

2004. Development of worker ovaries in brazilian africanized honeybees (Hymenoptera: Apidae). Sociobiology 44(3): 695-705.

. 2006. Ultrastructural aspects of the intercellular bridges between female bee germ cells. Brazilian Journal of Biology 66(1B):309-315.

Sakagami, S. F. 1954. Occurrence of the aggressive behavior in queenless hives, with considerations on the social organization of honeybee. Insect Sociaux 1:331-43.

Sakagami, S. F.; Beig, D.; Zucchi, R. \& Akahira, Y. 1963. Occurence of ovary-developed workers in queenright colonies of stingless bees. Revista Brasileira de Biologia 23(2):115-29. 